\title{
SPATIAL PRICE CONNECTIVITY IN MARKETING BEEF CATTLE IN KUPANG REGENCY, INDONESIA
}

\author{
Tiro Melkianus*, Lalus Matheos F. \\ Faculty of Animal Science, Nusa Cendana University, Kupang, Indonesia \\ ${ }^{*}$ E-mail: roynendissa@staf.undana.ac.id
}

\begin{abstract}
Farmers as producers in the process of fattening cattle are needed a long time between 6 (six) months to 1 (one) year longer. It is expected that the proceeds from the sale of cattle raised will provide an adequate imbalance. The research was used survey method, data analysis was performed by S-C-P analysis. Objectives: 1) Analyze market connectivity spatially, both in the short and long term in marketing beef cattle in Kupang Regency, NTT. 2) Analyzing selling prices in cattle marketing and 3) Analyzing increasing markets in marketing cattle producing. Conclusions: 1) Spatial market connectivity between farmers and inter-island traders in the short term is imperfect which is translated by the regression coefficient ( $b 1=0.79$ ); the same thing is even weaker the price connectivity between opposing traders and farmers associated with the regression coefficient $(b 2=0.19)$ while the price connectivity between the related traders and inter-island traders is complete as presented by the regression coefficient $(\mathrm{b} 3=1.0851)$. In the long term, there is a connectivity between the prices of cattle, both at the level of farmers and traders, traders and traders between islands and between farmers and traders between islands. 2) Transmission of prices between farmers and traders between islands is not perfect, the price of beef cattle transmission between farmers and traders also is not perfect; inter-island traders and interisland traders prices go perfectly. 3) The average share of farmers is $60.59 \%$. Its marketing margins are still quite high at $38.66 \%$. Margin distribution is not proportional among marketing institutions involved in marketing beef cattle. Profit and margin ratios, for traders participation $87.98 \%$ and inter-island traders only $62.10 \%$. The ratio of total profits to marketing margins is $76.13 \%$.
\end{abstract}

\section{KEY WORDS}

Connectivity spasially, farmers, price transmission, marketing margins.

Farmers as producers in conducting the production process (fattening beef cattle) which need a long time (between 6 (six) months to 1 (one) year or even longer). During the period of fattening; they have sacrificed a lot of time, energy and money. The expectation of farmers to get rewards in the form of an adequate selling price is still difficult to realize because of various obstacles that are beyond their ability to overcome them, such as: inadequate marketing infrastructure, information asymmetry (Anindita, 2004), where farmers live far from cities and spread geographically with inadequate road infrastructure conditions, the purpose of farmers raising cattle is not yet market-oriented, but only as a precautionary measure (as savings) that can be used to meet urgent needs, the number of livestock sold is only around $1-2$ heads, transportation costs are still quite expensive if you have to sell to the cattle market.

Meanwhile, on the merchant's side, when viewed from the point of time, the traders only need about two weeks to a month to move a cow from a farmer until it reaches the consumer in the form of meat, a very short period of time when compared to the time all a farmer needs in maintaining and fattening a cattle until it is ready to be slaughtered. But the risks faced by traders in an effort to bridge farmers and consumers are not easy. The biggest risk is when collecting cattle from farmers to meet the quota to be transported from the farm gate in remote villages with poor road infrastructure; possible animal accident in the form of broken leg, transportation costs, feed costs during collection, labor costs and other costs. 
These are the things that cause traders to ask for low cattle prices at the farm level, so that in turn the income is also low.

Base on the above situation causes farmers to have a weak bargaining position compared to traders, consequently farmers only act as price takers (Lalus et al. 2018), while traders act as price setter. The situation of such farmers is expected to cause a large price disparity in the marketing of cattle in this region. The situation of price disparity among market participants will affect the transmission of prices from the reference market to the underlying market; then it will affect the price connectivity spatially. The questions are: 1) Is there a spatial integration of markets in cattle marketing in Kupang NTT Regency? 2) How to transmit prices among price participants! 3) What is the conduct of the cattle market in cattle marketing in Kupang Regency?

Research purposes:

- Analyze market connectivity spatially, both in the short and long term in marketing beef cattle in Kupang Regency, NTT;

- Analyzing the transmission of prices in cattle marketing in Kupang Regency;

- Analyzing market performance in marketing beef cattle in Kupang NTT Regency.

\section{METHODS OF RESEARCH}

This research was conducted in Kupang Regency, because this region is one of the regencies with the second highest number of cattle population after South Central Timor Regency in East Nusa Tenggara. Two sample districts were selected purposively namely Amarasi District and Fatule'u District.

Data needed for this study includes primary data and secondary data. Primary data were obtained from interviews and direct observations with sample breeder farmers. While secondary data are sourced from various agencies related to this study starting at the provincial, district, sub-district and village levels.

The method used in this study is a survey method, which is an investigation carried out to obtain the facts of various symptoms that exist, and look for factual information or empirical phenomena. The survey method dissected, skinned and hit various problems and justified the conditions and practices that are taking place (Silalahi, 2010; Bungin, 2014).

Determination of respondents carried out through simple random sampling (random sampling). While the number of respondents for traders / entrepreneurs engaged in marketing / trading of cattle includes cattle traders (village / sub-district), and inter-island traders (district / province), adjusted for the number found in the field with snow ball sampling technique.

The method of data collection is done by direct interview techniques with respondents, based on a list of questions that have been prepared previously. Data collected includes primary data and secondary data. Primary data was obtained from farmers, traders involved in marketing cattle from cattle to cattle arrived in the hands of whole sale receiver traders in Jakarta. Whereas secondary data was collected from agencies / institutions related to this study ranging from villages to provinces and nationally.

The method used to analyze this research data is the Structure, Conduct and Market Appearance (S-C-P) approach. To analyze the structure of the cattle market in Kupang NTT Regency through this approach a simple linear regression analysis is used according to the level of the market that cattle is traversing in this region.

The approach used to determine the institutional structure of the market at various levels of beef cattle market in Kupang Regency is a) concentration ratio analysis, b) elasticity analysis of price transmission and c) descriptive analysis to see barriers to market entry.

The concentration ratio $(\mathrm{CR})$ in this study is intended as the number of beef cattle purchased by certain traders compared to the number of beef cattle traded on the market. According to Hay and Morris (1991) cited Widiyantara (1995) that the concentration ratio ( $\mathrm{Kr})$ can be known by using the formula as:

$$
\mathrm{CR}=(\text { Amount purchased }) /(\text { Amount traded }) \times 100 \%
$$


If there is one trader who has (CR1) at least 95\% of the market share, then the market tends to monopsonic competition. If there are four traders who have (CR4) of at least $80 \%$, then the market tends to oligopsonic competition with high concentration. Whereas if eight traders (CR8) have a minimum of $80 \%$, then the market tendency leads to an oligopsonistic market structure with moderate concentration. Meanwhile, according to Anindita (2017), concentration ratio for the biggest four or CR4 is an analysis tool to determine the fourth degree of the largest market share of a market region with the following criteria: 1 ) when CR4 $<0.4$, then the market structure is perfectly competitive (competitive) or Monopolistic competition in this condition needs to be seen whether there is product differentiation or not; 2 ) at $0.4 \leq C R \leq 0.8$, the market structure is oligopoly or oligopsonistic. If the CR4 value is between $60-80 \%$, it is called a tight oligopoly, whereas if the CR4 value is between $40-60 \%$ it is called a loose oligopoly. Because this meaning is often unclear, measurements of oligopoly or monopoly power can be tested through market power; and 3) when CR4>0.8, the market structure tends to be monopolistic or monopsony.

Analysis of price transmission elasticity is used to determine the price response of agricultural commodities, in this case the price of beef cattle at the farmer level due to price changes at the consumer level (price changes at the level of whole sale receiver traders in Jakarta) through price information (Azzaino, 1981).

The elasticity of price transmission between the central market, in this case the market at the level of large recipient traders in Jakarta and the local market in this case the price at the farm level can be analyzed using the model as Sexton, King and Carman (1991) show as follows:

$$
\operatorname{LnPf}=\mathrm{Lnb0}+\mathrm{Lnb1Pap}
$$

Where: Pf $=$ Prices at the local / farmer level (IDR / head); Pap = Price at the central market / wholesaler level of Jakarta (IDR / head); b1 = coefficient of price elasticity.

This price transmission elasticity can also be seen by using the ratio of average prices at the level of farmer farmers (Pf) and the average prices at the level of large recipient traders in Jakarta. To calculate the price transmission elasticity $(\eta)$ is as follows:

$$
\eta=\partial \operatorname{Pr} / \partial \operatorname{Pf} \times \operatorname{Pf} / \operatorname{Pr}
$$

Where: $\mathrm{n}=$ price transmission elasticity; Pap = Prices at the inter-island trader level (IDR / head); $\mathrm{Pf}=$ price at the level of farmer farmers (IDR / head).

Since it is assumed that $\operatorname{Pr}$ and $\mathrm{Pf}$ have a linear relationship, $\partial \mathrm{Pr} / \partial \mathrm{Pf}=\mathrm{b}$, which is also the same as the regression coefficient. Thus the regression coefficient in the equation below directly becomes the coefficient of price transmission elasticity:

$$
\mathrm{LnPf}=\mathrm{b} 0+\mathrm{b} 1 \mathrm{LnPap}
$$

If $\mathrm{b} 1<1$ means that if there is a change in price at the consumer level (large recipient traders in Jakarta) by $1 \%$, then the farmer will receive a price change $<1 \%$, this means the market is in an imperfect competitive condition. Whereas if $b 1=1$, it means that if there is a change in price at the receiving wholesaler level in Jakarta by $1 \%$ then the price change is transmitted by $1 \%$ to the price change at the farmer level, it means the market is in a perfectly competitive condition, and if b1>1, it means if there is a price change at the level of large recipient traders in Jakarta by $1 \%$, then the price change causes price changes greater than $1 \%$ at the farmer level, this means the market is in an imperfect competitive condition.

To find out the cattle market behavior in Kupang Regency, East Nusa Tenggara, it is done through a qualitative approach and a quantitative approach. Qualitative approach is an approach that is done descriptively to find out the practices of pricing in the study area. Whereas quantitatively, this is done through a market integration approach both in the short and long term. 
The method of analysis used in this study is the analysis of vertical market integration to determine the relationship and influence of prices at various different levels, namely at a lower market level one level below or higher one level above.

According to Sexton, King and Carman (1991), to find out the price between two integrated markets or not use simple linear regression analysis with the equation model adjusted to the market level as follows.

Integration Model for Beef Cattle Market between Farmer Farmers (Pf) and Inter-Island Traders (Pap):

$$
P_{f}=\beta_{0}+\beta_{1} P_{a p}+e_{t}
$$

Where: $\mathrm{Pf}=$ price at farmer level/farm gate price (IDR / head); Pap = Prices at the interisland trader level (IDR / head); $\beta 1=$ regression coefficient; $\beta 0=$ intercept.

If $\beta 1=1$, it means that in the short term, the market between farmers and inter-island traders is perfectly integrated, which means that if there is a change in the price of large traders in Jakarta by $1 \%$ it will cause a change in prices at the level of farmer farmers by $1 \%$ as well; if $\beta 1<1$, it means that the market is not perfectly integrated, so that if there is a change in prices at the wholesaler level in Jakarta by $1 \%$, it will cause changes in the price of farmers $<1 \%$ and if $\beta 1>1$, then the market is in the situation is not perfectly integrated, so that if there is a price change at the level of large traders in Jakarta by $1 \%$, it will not cause a change in prices at the level of farmer farmers> $1 \%$.

Integration Model for Beef Cattle Market between Farmers (Pf) and Intermediary Traders (Pp):

$$
P_{f}=\beta_{0}+\beta_{1} P_{p}+e_{t}
$$

Where: $\mathrm{Pf}=$ price at farmer level/farm gate price (IDR / head); $\mathrm{Pp}=$ Prices at the level of intermediary traders (IDR / head); $\beta 1=$ regression coefficient; $\beta 0=$ intercept.

If $\beta 1=1$, it means that in the short term, the beef cattle market between breeder farmers and intermediary traders is in a perfectly integrated state, which means that in the short term, if there is a change in prices of inter-island traders by $1 \%$, it will cause a change in prices in the level of farmer farmers by $1 \%$ also, if $\beta 1<1$, it means that in the short term, the market is in a state that is not perfectly integrated, so that if there is a change in prices at the inter-island trader level of $1 \%$, it will cause changes in prices at the farmer level $<1 \%$ and if $\beta 1>1$, it means that in the short term, the market is not perfectly integrated, so if there is a price change at the inter-island trader level of $1 \%$ it will not cause price changes at the farmer level of farmers> $1 \%$.

Integration Model for Beef Cattle Market between Intermediary Traders (Pp) and Interisland Traders (Pap):

$$
P_{p}=\beta_{0}+\beta_{1} P_{a p}+e_{t}
$$

Where: $P p=$ Prices at the level of intermediary traders (IDR / head); Pap $=$ Prices at the inter-island trader level (IDR / head); $\beta 1=$ regression coefficient; $\beta 0=$ intercept.

If $\beta 1=1$, it means that in the short term, the beef cattle market between intermediary traders and inter-island traders is perfectly integrated, which means that if there is a change in prices at inter-island traders by $1 \%$, it will cause a change in prices at the level of intermediary traders by $1 \%$ also, if $\beta 1<1$, it means that in the short term, the market is in a state of not being fully integrated, so that if there is a price change at the inter-island trader level of $1 \%$, it will cause price changes at the level of intermediary traders $<1 \%$ and if $\beta 1>1$, means that in the short term, the market is not perfectly integrated, so that if there is a change in price at the inter-island trader level of $1 \%$, it will not cause price changes at the level of intermediary traders> $1 \%$.

Integration Model for Beef Cattle Market between Farmers (Pf), Intermediary Traders (Pp) and Inter-island Traders (Pap): 


$$
P_{f}=\beta_{0}+\beta_{1} P_{p}+\beta_{2} P_{\text {pap }}+e_{t}
$$

Where: $\mathrm{Pp}=$ Prices at the level of intermediary traders (IDR / head); Pap = Prices at the inter-island trader level (IDR / head); $\beta 1=$ regression coefficient; $\beta 0=$ intercept.

If $\beta 1=\beta 2=1$, it means that in the short term, the beef cattle market between breeder farmers with intermediary traders and inter-island traders is perfectly integrated, which means that if there is a change in prices at inter-island traders by $1 \%$, it will cause price changes at the level Intermediary traders and ranchers by $1 \%$ also, if $\beta 1 \neq \beta 2 \neq 1 \%$, it means that in the short term, the market is not perfectly integrated, so that if there is a change in price at the inter-island trader level of $1 \%$, it will cause price changes at the level of intermediary traders and farmers $\neq 1 \%$, meaning that in the short term, the beef cattle market between cattle farmers and intermediary traders and inter-island traders is not perfectly integrated.

Analysis of price changes is a dynamic analysis, while the equation models (4.5a) to (4.5d) above are static analyzes, so they are only able to show the state of price integration in the short term. The approach used in long-term market integration is the autoregression model, which is a dynamic approach to price changes in a market. The general model of autoregression (AR) (Ravallion, (1986) and Timmer (1987) cited by Anonymous (1996) can be expressed by Pft (farm gate price) which is a linear function of the value of lag of selfesteem expressed in the form of equations mathematically as follows:

$$
P f t=a 1 P f t-1+a 2 P f t-2+\ldots+\text { asPft-s }+ \text { Et }
$$

Or it can be simplified to:

$$
\begin{aligned}
& \mathrm{Pft}=\sum \text { ai Pft-s }+\varepsilon \mathrm{t} \\
& \quad \text { or }(1-\mathrm{a} 1 \beta) \mathrm{Pft}=\varepsilon \mathrm{t}
\end{aligned}
$$

Ravallion (1986) states that price changes in a market are a function of several independent variables.

$$
P f t=f(\text { Pft-s, Prt, Prt-1, Prt-j, Xj) }
$$

Where: Pft $=$ Local market price of the t-year; Pft-s $=$ Lag of self-esteem; Prt $=$ Reference market price (consumer price. Price on inter-island traders); Prt-j = Lag price in the reference market; $\mathrm{Xj}=$ Other external variables; $\mathrm{s}=$ Length of price lag at time $\mathrm{t}-\mathrm{s} ; \mathrm{j}=$ Length of the reference price lag.

The above function equation (equation 8 ) is rewritten in the form of an autoregression vector as follows: where $s=1,2,3, j=0,1,2,3$.

- If bij $=0(j=1,2, \ldots, n)$ means the price in the reference market does not affect the price in the local market;

- If bi0 $=1$, then ais $=$ bij $=0(j=1,2, \ldots, n)$ means that the price increase in the reference market will immediately be distributed perfectly to the price in the local market, so it is said that in the second short term perfectly integrated market;

- If ais + bij $=1(j=0,1,2, \ldots, n)$ means in the long run the price in the reference market and the local market is perfectly integrated.

According to Ravallion (1986) that by applying the autoregression vector above, a serious multicollinearity problem will be found among the regressors in the model used, so that it will lead to biased estimation results. Lots of multicollinearity that must be avoided so it requires a complicated process. Furthermore, to overcome the multicollinearity problem in the Ravallion model, he and Timmer (1987) cited Anonymous (1996) simplified the model as follows:

$$
(P f t-P f t-1)=(b 1-1)(P r t-1-P f t-1)+(b 1+b 0+a 1-1) P f t-1+C t X t+e t
$$




$$
P f t=(1+d 1) P f t-1+d 2(P r t-P f t-1)+(d 3-d 1) P r t-1+d 4 X t+e t
$$

Where: $d 1=(b 1-1) d 3=b 1+b 0+a 1-1 ; d 2=b 0 d 4=c$.

According to Timmer (1987), the coefficients $(1+\mathrm{d} 1)$ and $(\mathrm{d} 3-\mathrm{d} 1)$ illustrate the contribution of prices to farmers and consumers in the past to the formation of farmers' prices at the present time. Market integration in the short term is measured through the Index of Market Connection (IMC):

$$
\mathrm{IMC}=((1+\mathrm{d} 1)) /((\mathrm{d} 3-\mathrm{d} 1))
$$

If the IMC value is close to zero (IMC $\approx 0$ ) it means that the market is increasingly integrated in the short term. That is, the conditions of supply and demand in the reference market are effectively transmitted to the local market and affect prices in the local market. The integration in the long run is shown by the coefficient $\mathrm{d} 2$ because these parameters indicate how much price changes at the consumer level can affect prices at the farm level at this time. If (Pft - Prt- 1$)=0$, then $\mathrm{d} 2$ is excluded from the equation, which means the consumer market price is stable. When $\mathrm{d} 2$ approaches $1(\mathrm{~d} 2 \approx 1)$, the two markets are increasingly integrated in the long run.

Researchers have used many models developed by Ravallion mentioned above, including Timmer (1987), Research Team of the Commissariat of the Perheppi Surakarta (1996). In this study, to determine the vertical long-term price integration, the autoregression model is used:

$$
P_{\text {f.i.t. }}=\alpha_{o i}+\alpha_{1 i}\left(P_{\text {f.i.t-1 }-1}\right)+\alpha_{2 i}\left(P_{\text {r.j.t. }}-P_{\text {r.j.t.-1 }}\right)+\alpha_{3 i}\left(P_{\text {r.j.t. }-1}\right)+e_{t}
$$

Where: Pf.i.t $=$ Price of cattle at the i-t month farmer level $t$ (IDR / head); Pf.i.t-1 = Price of cattle at the i-t-1 month farmer level (IDR / head); Pr.j.t = Price of cattle at the i-th trader level in the $\mathrm{t}$ month (IDR / head); Pr.j.t-1 = Price of cattle at the $\mathrm{i}$-th trader level in the $\mathrm{t}-1$ month (IDR /head.

If $\alpha 2 i=1$, in the long run the price of cattle at the $i$-farmer level is perfectly integrated with prices at the $\mathrm{j}$-th trader level, which means that if there is a change in the price of large traders in Jakarta by $1 \%$, it will cause changes in prices at the farm level breeders by $1 \%$ also, if $\alpha 2 i<1$, in the long run the price of cattle at the i-farmer level is not perfectly integrated with prices at the j-trader level so that if there is a change in prices at the level of large traders in Jakarta by $1 \%$, will cause changes in prices at the level of farmers $<1 \%$ and if $\beta 1>$ 1 , means the market is in a state that is not perfectly integrated, so that if there is a price change at the level of large traders in Jakarta by $1 \%$ will cause changes in prices at the level of farmers farmers breeders $>1 \%$. Furthermore, by using the equation model (4.12) it can also be known the state of integration in the short term; You can also search Index of Market Connection (IMC) values:

$$
I M C=\frac{\alpha 1 \mathrm{i}}{\alpha 3 \mathrm{i}}
$$

If $\mathrm{IMC}=0$, it means that in the short term the price at the farm level is perfectly integrated with the price at the level of the recipient wholesaler in Jakarta. If the IMC is> 0 , it means that in the short term the price at the farm level is not perfectly integrated with the price at the level of the wholesaler reciever in Jakarta.

To find out the performance of the beef cattle market in Kupang NTT, an analysis was conducted with the farmer's share, marketing margins and distribution of profit shares among marketing institutions involved in cattle marketing activities in the region.

$$
F S=\frac{P f}{P a p} \times 100 \%
$$

Where: FS = Farmer's Share; $\mathrm{Pf}=$ Prices at the level of farmer farmers/farm gate price IDR / head); Pap $=$ Prices at the consumer level (big traders in Jakarta) $(\mathrm{Rp} /$ head $)$. 
Marketing margin is the difference in price paid at the consumer level (inter-island trader) with the price received at the farmer level. Hanafiah and Saefuddin (2006) stated that the trading system margin is the price difference at the two levels of the trading system multiplied by the number of products marketed. Marketing margins will be seen at every level of the market: collectors, wholesalers and retailers. So by knowing the margins in each market, it can be seen whether each existing institution has received compensation in accordance with their respective contributions.

Rahim and Hastuti (2008) stated, in order to know the distribution of margins, it is necessary to know in advance that marketing margins consist of costs to carry out marketing functions and profits of marketing institutions involved in marketing an agricultural commodity. For this reason, it can be determined what percentage of the margin distribution is used as a cost in the implementation of marketing functions at each marketing institution.

Margin distribution is determined by the percentage of the total marketing margin used to carry out the $i$-th marketing functions by the $j$-th marketing agency and the profit of the $j$ th marketing institution. The distribution of marketing margins among marketing institutions involved in the marketing of beef cattle in Kupang Regency is analyzed with the following model.

Marketing margins 1 Inter-island trader (Pap) and intermediary trader (Pp):

$$
\begin{gathered}
\mathrm{MM}=\mathrm{Pap}-\mathrm{Pp} \\
\mathrm{Pap}=\text { Prices at the inter-island trader level }(\mathrm{IDR} / \text { head }) \\
\mathrm{Pp}=\text { Prices at the level of intermediary traders }(\mathrm{IDR} / \text { head }) \\
\text { Or } \mathrm{MM}=\sum \pi+\sum \mathrm{C}
\end{gathered}
$$

Where: $\Sigma \pi=$ Total profit of the intermediary agency; $\Sigma C=$ Amount of costs incurred by intermediaries.

$$
M M=(\operatorname{Pr}-\mathrm{Pf}) \sum \mathrm{Qf}, \mathrm{r}
$$

Where: $\Sigma Q f, r=$ Number of products traded (from producers to consumers).

Part of the costs for the implementation of the $\mathrm{i}$-th marketing function by the $\mathrm{j}$-th marketing agency is:

$$
\begin{aligned}
& S b i=\frac{B j}{(\operatorname{Pr}-P f)} \times 100 \% \\
& K j=P j i-P b i-\sum B i j
\end{aligned}
$$

Where: $\mathrm{SKj}=$ Share profits of the jth intermediary institution; $\mathrm{Kj}=$ profit of the jth intermediary institution; $\mathrm{Pji}=$ Selling price of the $\mathrm{i}$ intermediary institution; $\mathrm{Pbi}=$ The buying price of the $\mathrm{i}$ intermediary institution; $\mathrm{Bij}=$ Cost of marketing the $\mathrm{i}$-th agency and type; jth cost $(\mathrm{j}=1$ to $\mathrm{n}$ ).

The more equitable distribution of skiing in each marketing institution involved in marketing cattle, the more efficient marketing system is said.

\section{RESULTS AND DISCUSSION}

Based on the total farmer respondents, 52 people $(65 \%)$ sell directly to inter-island traders while $28(35 \%)$ others sell through intermediary traders. This means that most farmers in Kupang Regency no longer sell their cattle through intermediary traders; because inter-island traders in this region directly buy cattle from farmers. The results of this study differ from the results of research conducted by Lalus, et al (2018) for the same commodity, where it was found that $70 \%$ of farmers selling their livestock (cattle) through intermediary 
traders, because at that time the reasons put forward by farmers that the place weighed livestock located in an inter-island port. However, the results of this study show the opposite, because at the time of the study the weighing place for livestock was located close to where the breeder farmers were. In Amarasi District, it is located at Ponain Village, while for Fatuleu District, weighing tools are found in the Lili cattle market. Weighing tools on the market have all been damaged and there has been no attempt to replace them with new ones, or efforts to repair old ones that have been damaged.

Some cattle marketing channels in Kupang Regency are as follows:

- The first channel; farmers (Pf) sell to intermediary traders at an average price of IDR.7,518,333.33 / ST; then from intermediary traders (Pp) to inter-island traders (Pap) with an average price of IDR. 9,272,863.10 / ST, then Pap to the beneficiary wholesaler (Wsr) in Jakarta with an average price of IDR. 12,255,943.45 / ST and from large recipient wholesalers in Jakarta sold to $\mathrm{RPH}$ in the region;

- The second channel; farmers (Pf) directly sell to inter-island traders (Paps) with an average price of IDR 9,272,863.10 / ST. Continuing inter-island traders sell to recipient traders in Jakarta at an average price of IDR. 12,255,943.45 / ST and from large beneficiary traders in Jakarta - RPH - Beef consumers;

- Third channel: breeder farmers (Pf) sell feeder cattle: 1 ) directly to other farmers who are fattening at an average price; IDR.4,880,952.38 with an average age of feeder animals 22.8 months and 2) through the animal market both after the feeder cattle are fattened and then resold such as channel a) and b);

- Channel Four: farmers (Pf) sell directly to butchers at local slaughterhouses (in Kupang), in general cattle sold directly to local slaughterers are female animals that can no longer be produced; In addition, it still depends on the farmers' need for cash, and does not even need to sell pregnant female cows. The average price of female cattle sold by farmers is IDR.6,105,263.16.

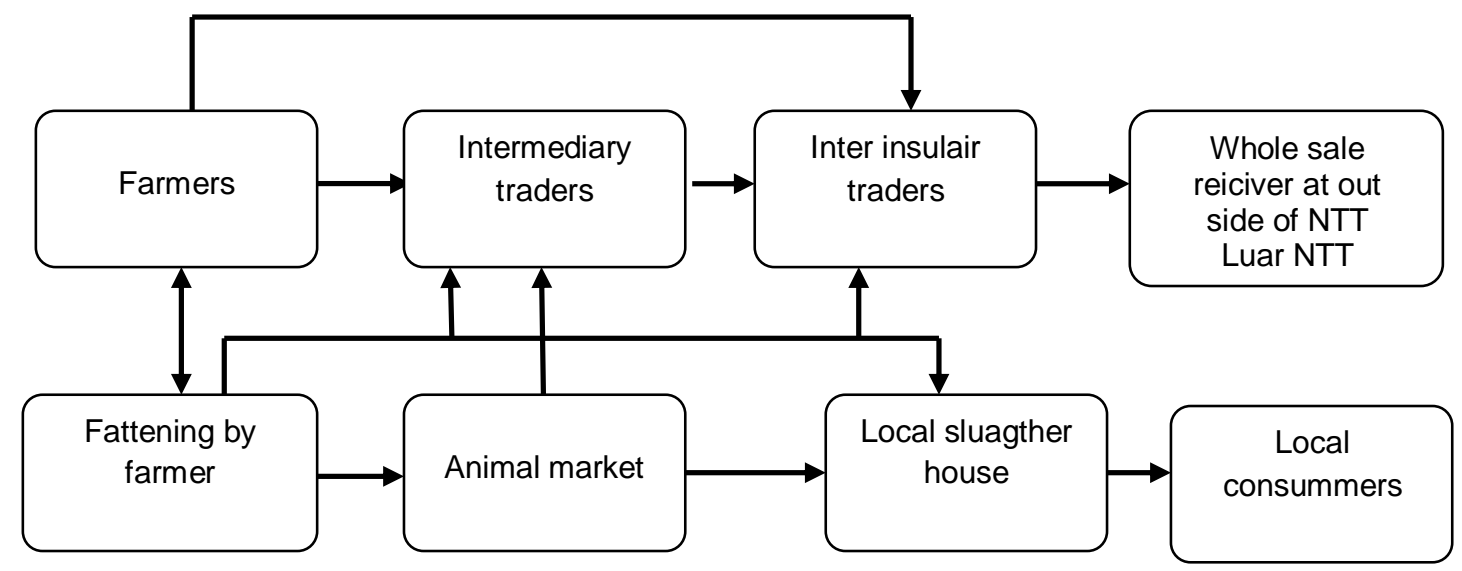

Figure 1 - Cattle marketing channel in Kupang NTT Regency

All cattle are transported by inter-island traders from Kupang Regency, where wholesale receiver traders in Jakarta have a slightly different way of determining the price of the product when there is a price determination at the farm level, where the price determination is carried out on the basis of live weight or estimation of the external body condition of cattle being transacted. While the determination of the price of livestock at the level of whole sale reciever traders in Jakarta and Kalimantan is no longer based on the weight of life but on whether or not a cow is weighted, even after weighting is done to group the price to determine the price.

Analysis of market connectivity is an integral part of the analysis of market structure, market behavior and market performance. Before explaining about the analysis of market connectivity, it is first stated the notion of market connectivity as stated by experts, among others; Ravallion (1986) that markets are spatially connected when trading activities occur between these markets. In line with Ravallion's opinion above, according to Muwanga and 
Snyder (1997) and Setiadi (2010) that, markets are said to be connected if there is trading activity between two or more markets that are spatially separated, then prices in a market are related or correlated with prices in other markets. Spatial or total price changes in a market are transmitted to other markets, both in the short and long term. It is almost certain that there is a correlation between the price of beef cattle at every level of the market that is passed by a cattle, starting from the farm gate to finally reaching the consumers in the form of meat. As stated above that market integration is an inseparable part of the S-C-P analysis, then the sequence of analysis starts from the market structure, market conduct and market performance.

Market structure analysis in this study was carried out through two approaches namely the qualitative approach and the quantitative approach (Soekirno, 2015). First, a qualitative approach can be made by looking at the number of sellers and buyers and barriers to and from the market. If seen from the number of farmers as the main source of origin of beef cattle is very much compared to the number of intermediary traders / village beauticians who are very small in number and inter-island traders of no more than five people, then the structure of the beef cattle market in Kupang Regency is oligopsonistic. Second, a quantitative approach to determine the institutional structure of the market at various levels of the beef cattle market in Kupang Regency is a) concentration ratio analysis, b) analysis of price transmission elasticity and c) descriptive analysis to see barriers to market entry.

The concentration ratio in this study is intended as the number of beef cattle purchased by certain traders compared to the number of beef cattle traded on the market. In this study there were 10 intermediary traders who bought beef cattle from breeder farmers with transaction volume ranging from 26 - 95 tails or ranging from $5.10 \%-18.63 \%$ each trader from the purchase volume on the market. According to Hay and Morris (1991) quoted by Widiyantara (1995) that the concentration ratio ( $\mathrm{Kr}$ ) can be known by using the formula as shown in equation (1)

If we look at the number of intermediary traders who are only 10 people compared to 80 farmers, the structure of the beef cattle market in Kupang NTT has a tendency towards oligopsonistic competition. Furthermore, when viewed from a concentration ratio in which four traders only controlled $56.08 \%$ of the transaction volume in the market, it appears that it is still far from the minimum requirement of $80 \%$, even if seen from the number of transactions from only 8 traders only reached $89.41 \%$, the structure of the beef cattle market in this region leads to oligopsonistic competition with moderate concentration.

Furthermore, when viewed from inter-island traders whose numbers are far fewer, namely only 4 people, the structure of the beef cattle market in Kupang NTT has a tendency towards oligopsonistic competition. While the ratio analysis results show that two inter-island traders who control the market transaction volume of $58.80 \%$, the structure of the beef cattle market in NTT has a tendency towards oligopoly competition with moderate concentration. Bain (1959) cited by Erlinda, et al (2008) states that, after understanding the level of market concentration, market characteristics can be identified whether monopoly, oligopoly, monopolistic or perfect competition. A market is called: a) monopoly if the value of CR4 (market concentration level of the four largest companies is greater than $70 \%$; b) oligopoly if the value of CR4 is greater than $40 \%$ but less than $70 \%$.

Analysis of price transmission elasticity is used to determine the price response of agricultural commodities, in this case the price of beef cattle at the farm level due to price changes at the consumer level (price changes at the level of large recipient traders in Jakarta) through price information (Azzaino, 1981).

To find out the structure of the beef cattle market in Kupang Regency, it can be done through simple linear regression analysis. This analysis is conducted to determine the price response at the farmer level as a result of price increases that occur at the inter-island trader level. This analysis is also referred to as price flexibility analysis.

The results of data analysis show that the simple linear regression model between farm-gate prices and inter-island trader prices (table 1) shows that the coefficient (b1 = 0.7929) means that the transmission of beef cattle prices in Kupang Regency between farmers and inter-island traders does not take place perfectly. This means, if there is a price 
change in the reference market, in this case the Jakarta market by $1 \%$ will only be transmitted by $0.79 \%$ to the farmer level, so that it can be said that the price changes that occur in Jakarta then the price change is not immediately enjoyed by the market level at the bottom in this case the farmers. In other words, there is still a price reduction made by interisland traders when buying cattle directly from farmers; this is also one of the forms of asymmetry of market information created by many factors such as the creation of a condition where farmers are reluctant to sell their livestock based on live body weight, because the distance between farmers' dwellings is quite far from the weighing place of livestock; Another thing that also reinforces this reason is that the weighing tools available on the Lili market, which are relatively close to farmers, have been damaged in the past few years, and there has been no attempt to repair them.

The coefficient of determination $\left(R^{2}=0.5832\right)$ shows that the model of estimating the transmission of prices as shown in table 1 is quite good; because the factors involved in the model that is the price of $58.32 \%$ influence on the transmission of prices while $41.68 \%$ is caused by other factors not involved in the model.

The results of a simple linear regression analysis between prices at the farm level and prices at the level of intermediary traders (see table 1). From the table it is known that the coefficient $b 1=0.1926$, where tcount $>$ ttable $=3.6361>2.167$ ), thus concluded that means the transmission of beef cattle prices between farmers and intermediary traders takes place imperfectly. This means that, if there is a change in price at the inter-island trader level of $1 \%$ it will also only transmit $0.19 \%$ by an intermediary trader to the farmer level. The coefficient $b$ $=0.1926$ can also be explained that one of the reasons is the determination of the price at the time the intermediary trader makes a transaction with the farmer which is not based on the live body weight of the cattle, but rather based on the estimation of the intermediary trader only on the condition of its external body. This indicates that intermediary traders will estimate the body weight is lower than if weighed. Errors or even intentions in terms of estimated live body weight of cattle in the transaction are quite large $80.74 \%$, while $19.265 \%$ estimates of intermediary traders and farmers are correct.

The coefficient of determination $R^{2}=0.1449$ shows that the model of estimating the transmission of the price of table 1 is not good, because the factor involved in the model that is the price only gives $14.49 \%$ of the price transmission, while $85.51 \%$ is determined by other factors not involved in model. Other factors that are intended include, among others, farmers in raising cattle are not yet market-oriented, they only sell their domestic cattle when cash needs are urgent, such as children's educational needs, or customary needs.

The results of data analysis show that the simple linear regression model between prices at the level of intermediary traders with prices at the level of inter-island traders (table 1). From the table it appears that the coefficient $b 1=1.0851$ ) where tcount $>$ ttable $=5.5008>$ 2.167), thus it is concluded that the transmission of beef cattle prices in Kupang Regency between intermediary traders and inter-island traders takes place perfectly. This means, if there is a price change in the reference market, in this case the Jakarta market by $1 \%$ is passed perfectly by $1 \%$ to the level of intermediary traders, so that price changes that occur in Jakarta are immediately enjoyed by intermediary traders as well. This is not surprising because in general intermediary traders do not have their own capital, they carry out trading activities for cattle because of capital from inter-island traders.

The coefficient of determination $\left(R^{2}=0.2795\right)$ shows that the model of estimating the transmission of prices as shown in table 1 is not good; because the factors involved in the model that is the price only gives $27.95 \%$ of the price transmission while only $72.05 \%$ is caused by other factors not included in the model.

Analysis of market conduct is carried out to determine the pricing practices in the market, both qualitatively and quantitatively. Qualitative pricing practices are described descriptively. While quantitative analysis can be explained with the help of vertical market integration analysis, starting from the level of breeder farmers to inter-island traders. Market integration analysis uses a simple linear regression model for the short and long term.

The practice of pricing by traders in Jakarta on beef cattle from NTT (especially Kupang Regency) or other regions in Indonesia and imported cattle based on the physical 
appearance of the livestock in question. There are 3 criteria for beef cattle imposed by Jakarta traders namely grade $A$ is beef cattle with fat body (attractive and attractive appearance), grade $B$ is medium-bodied cattle and grade $C$ is thin body, but in the end pricing based on live weight.

Vertical market integration aims to analyze the relationship of prices in one market with markets below or above. Based on data collected from inter-island traders (having complete notes on a periodic weekly or monthly basis on the purchase price and selling price of beef cattle successfully delivered for three years ie from 2016 to 2018), prices for cattle tend to vary.

The average price of beef cattle at various market levels is as follows: the average price of beef cattle in 2016 was IDR. 4,609,348.46 in 2017 increased by $4.74 \%$ to IDR. $4,827,825.77$ then up another $20.64 \%$ to IDR. 5,824,174.37 in 2018. Whereas, if observed from the acceptance of farmers, intermediary traders and inter-island traders (inter insulair) also increased respectively for farmers by $3.10 \%$ in 2017 to $8.76 \%$ in 2018 ; for intermediate traders decreased by $2.95 \%$ in 2017 to $1.00 \%$ in 2018 . Inter-island traders' acceptance increased by $10.68 \%$ in 2017 and fell to only $2.85 \%$ in 2018 . This phenomenon may be narrated that lately the introduction of livestock islands from NTT have been rationed around 60 thousand heads each year, while the number of interinsulair traders is quite a lot ie around 100 traders. So if the ration of the number of livestock delivered is explained for each month only as much as 5 thousand head. If the amount is distributed to 100 traders, each trader has a quota of approximately 50 heads of cattle per month. Not to mention the share of the number of livestock is divided by the number of cattle-producing areas in NTT, so surely every trader will be less rationed. This is what causes the sale and purchase of permits in cattle herding so that NTT rations in transporting livestock are maintained.

Price connectivity at various market levels in the study area, in the short term the results of a simple linear regression analysis and the results are shown in table 1.

Table 1 - Estimation Results of Regression Coefficients (Vertical Market Integration) in the Short Term by Market Level of Beef Cattle in Kupang District, NTT

\begin{tabular}{|c|c|c|c|}
\hline \multirow{2}{*}{ Variables } & \multicolumn{3}{|c|}{ Market levels } \\
\cline { 2 - 4 } & Pf - Pp & Pf - Pap & PP - Pap \\
\hline Constanta (b0i) & 12.7154 & 0.8812 & -1.7271 \\
Prj(t)(b1i) & 0.1926 & 0.0759 & 1.0852 \\
Se (b1i) & 0.0538 & 10.4477 & 0.1973 \\
$\mathrm{t}_{\text {count }}$ & 3.6361 & 109.154 & 5.5008 \\
$\mathrm{~F}_{\text {count }}$ & 13.22 & 0.5832 & 30.26 \\
$\mathrm{R}^{2}$ & 0.1449 & 0.2795 \\
\hline
\end{tabular}

The short-term beef cattle price connectivity between farmers and intermediary traders in Kupang Regency is shown by the regression coefficient $(b 1=0.1926)$; means that if there is a price increase at the level of intermediary traders by $1 \%$, it will only be transmitted to breeder farmers only by $0.19 \%$. This means that the percentage increase in prices that is applied by intermediary traders to farmers is much smaller than the increase in prices received by intermediary traders themselves. So it is said that the price of beef cattle at the farm level is not perfectly connected to the price at the level of intermediary traders.

The short-term beef cattle price connectivity between farmers and inter-island traders in Kupang District is shown by the regression coefficient $(b 2=0.7929)$. This means that if there is a price increase at the inter-island trader level of $1 \%$, then the price increase will be transmitted to farmers by only $0.79 \%$. This means that the percentage increase in prices imposed by inter-island traders to farmers is not the same as the increase in prices received by inter-island traders from wholesale receiver traders in Jakarta. Thus it can be said that the price of beef cattle at the farm level is imperfectly integrated with prices at inter-island traders.

The short-term beef cattle price connectivity between intermediary traders and interisland traders is shown by the regression coefficient $(b 3=1.0852)$. This means that if there is a price increase at the inter-island trader level of $1 \%$, then the price increase will be transmitted to intermediary traders by $1 \%$. This means that the percentage increase in prices 
imposed by inter-island traders to intermediary traders is the same as the increase in prices received by inter-island traders from large recipient traders in Jakarta. So it can be said that the price of beef cattle at the farm level is not perfectly connected to the price at the interisland trader level.

Long-term price connectivity at farmers and intermediary traders is shown by the regression coefficient $(\alpha 2.1=0.0429<1)$, between intermediary traders and intermediate traders $(\alpha 2.2=0.0854<1)$ and between farmers and inter-island traders $(\alpha 2.3=0.0434<1)$ means that in the long run the price is good, at the level of farmer farmers and intermediary traders, intermediary traders and inter-island traders and between farmers and inter-island traders tend to be connected.

To find out the market appearance in the marketing of beef cattle in Kupang Regency, it can be seen from the price share received by farmer farmers (farmer share), marketing margins and the distribution of profits of marketing institutions.

The average price of beef cattle per head in Kupang Regency paid by inter-island traders in 2016, 2017 and 2018 respectively IDR. 9,986,631.03; IDR. 11,973,321.88 and IDR.16,285,586.38 while the average price received by farmers is IDR. 6,409,344.26; IDR.7,519,827.59 and IDR.8,924,074.07. Thus the share of the price received by the farmer farmer (farmer share) in Kupang Regency is 64.18\%; 62.80\% and $54.80 \%$ of the price paid by inter-island traders. The average farmer share for Kupang Regency is $60.59 \%$.

Marketing margin of IDR.4,737,610.12. Margin value of that size, distributed among intermediary traders who received IDR. 1,754,529.76 and inter-island traders received IDR.2,983,080.36. Margin distribution like this seems evenly distributed, but it is not fair between traders and inter-island traders, because the biggest risk lies with inter-island traders, in addition to the largest amount and component costs borne by inter-island traders. The amount of marketing margin for beef cattle in Kupang Regency is still quite high at $38.66 \%$. The average price of cattle received by farmers in Kupang Regency is IDR. 7,518,333.33.

Margin distribution and profit are not evenly distributed among marketing institutions involved in the marketing of beef cattle in Kupang Regency. This can be seen from the profit and margin ratio, where for intermediary traders $87.98 \%$ and inter-island traders only $62.10 \%$. The ratio of total profits to marketing margins is $76.13 \%$. This approach also supports the previous approach that beef cattle marketing in Kupang Regency is not efficient.

\section{CONCLUSION AND RECOMMENDATIONS}

Spatial price connectivity between farmers and inter-island traders in the short term takes place imperfectly as indicated by the regression coefficient $(\mathrm{b} 1=0.79)$; the same thing is even weaker the price connectivity between the intermediary trader and the farmer as indicated by the regression coefficient $(\mathrm{b} 2=0.19$ ) while the price connectivity between the intermediary trader and the inter-island trader takes place perfectly as shown by the regression coefficient $(\mathrm{b} 3=1.0851)$. In the long run there tends to be a perfect price connectivity for beef cattle, both at the level of farmers and intermediary traders, intermediary traders and inter-island traders and between farmers and inter-island traders.

The transmission of beef cattle prices between: a) inter-island farmers and traders does not take place perfectly, b) farmers and village brokers / village brokers take place imperfectly; c) between intermediary traders and inter-island traders takes place perfectly.

The average share price received by farmer farmers (farmer's share) in the Regency is $60.59 \%$. The marketing margin of beef cattle in Kupang Regency is still quite high at $38.66 \%$. Margin distribution and profit are not evenly distributed among marketing institutions involved in the marketing of beef cattle in Kupang Regency. The profit and margin ratio, for intermediary traders is $87.98 \%$ and inter-island traders is only $62.10 \%$. The ratio of total profits to marketing margins is $76.13 \%$.

Farmers should sell their livestock using standard pricing based on live body weight. One effort that needs to be done is the procurement of portable weighing devices. Weighing tools that have been placed closer to farmers, should be handled by permanent staff from the 
Animal Husbandry Department; so that if damaged immediately repaired so that it does not become a reason for traders not to weigh livestock in determining the selling price of cattle.

A container is needed that makes it easy for farmers to access cash when facing urgent needs, so that the bargaining position of farmers becomes strong and sells their livestock at the right time.

In the long run, it is necessary to provide continuous counseling and assistance to farmers so that in trying to market-oriented cattle, so far the reasons for farmers to keep livestock as a buffer risk, so that new cattle are sold when it comes when the need for cash is urgent; at a time like this bargaining position becomes weak.

\section{REFERENCES}

1. Agus Setiadi, 2010. Integrasi Spasial dari Pasar Sapi Potong di Jawa Tengah, Indonesia. Philippines Univ. Los Baños, College, Laguna (Philippines) Food and Agricuture Organization of the United Nations.

2. Anindita, R. 2017. Pemasaran Produk Pertanian. Penerbit ANDI Yogyakarta.

3. Anindita, R. 2004. Pemasaran Hasil Pertanian. Penerbit PAPYRUS. JIn Semolowaru Indah Blok I-15 Surabaya 60119.

4. 1996. Studi Analisis Keterpaduan Pasar Pada Sistem Pemasaran Komoditas Pangan Strategis. Kerjasama antara Kantor Menteri Negara Urusan Pangan dengan Pusat Studi Kebijakan Pangan and Gizi. Lembaga Penelitian Institut Pertanian Bogor.

5. Asmara, Rosihan and Ruri Ardhiani, 2010. Inetgrasi Pasar dalam Sistem Pemasaram Bawang Merah. AGRISE (Agricultural Socio Economics Journal) Vol. 10 No. 3, 164.

6. Azzaino, Z. 1981. Pengantar Tataniaga Pertanian. Institut Pertanian Bogor.

7. Bungin, 2014. Metodologi Penelitian Kuantitatif. Komunikasi, Ekonomi and Kebijakan Publik Serta IImu-ilmu Sosial Lainnya. Penerbit Kencana Prenada Media Group, Jakarta.

8. Erlinda, M; Vivi Evertina and Rahmat Nurcahyo, 2008. Structure, Conduct, and Performance Analysis in Palm Cooking Oil Industry in Indonesia Using Structure, Conduct Performance Paradigm (SCP). Proceeding, International Seminar on Industrial Engineering and Management Santika Hotel Jakarta, October 25th, 2008. ISSN 1978 774X.Download April 25th 2016 http://citeseerx.ist.psu.edu/

9. Hanafiah, A.M. and A.M. Saefuddin, 2006. Tata Niaga Hasil Perikanan. Penerbit Universitas Indonesia (UI-PRESS).

10. Lalus, Matheos F.; Z. Fanani; Bambang Ali Nugroho and Hari Dwi Utami, 2018. Analysis Of Beef Cattle Marketing In Kupang Regency, East Nusa Tenggara Province, Indonesia. Asian Academic Research Journal Of Multidisciplinary (AARJMD). Volume 5 Issue 5 (May 2018). http://www.asian academicresearch.org/maymd2018. html.

11. Muanga, Gertrude S. and Donald S. Snyder, 1997. Market Integration and the Law of One Price: Case Study of Selected Feeders Cattle Markets. Utah State University. Digital Commons@USU. Economic Research Institute Study Papers.

12. Rahim, Abd., Diah Retno Dwi Hastuti, 2008. Pengantar Teori and Kasus Ekonomika Pertanian. Penerbit Penabur Swadaya Jakarta.

13. Ravallion, M. 1986. Testing Market Integration. American Journal of Agricultural Economic Association. Volume 72 Number 3.

14. Sexton, Richard J.; C. L. King and Hoy F. Carman, 1991. Market Integration, Efficiency of Arbitrage and Imperfect Competition. Methodology and application to U.S Celery. American Journal of Agricultural Economics. Vol. 73 Number 3, August 1991.

15. Silalahi, Ulber. 2010. Metode Penelitian Sosial. Penerbit Refika Aditama Bandung.

16. Sudiyono, A. 2004. Pemasaran Pertanian. Edisi kedua UMM Press, Penerbitan Universitas Muhammadiyah Malang.

17. Sumitra, J. 2013. Pemasaran Ternak Sapi Potong Di kabupaten Ogan Komering Ilir, Sumatera Selatan. Buletin Petenakan Vol. 37 (1): 49-58, Februari 2013.

18. Widiyantara, I Made, 1995. Ketidakstabilan Harga Anggur di Tingkat Petani di Kecamatan Grokgak Kabupaten Buleleng. Tesis S2 Universitas Gajah Mada KPK Universitas Brawijaya Malang. 